Eugeniusz Ponczek

Uniwersytet Łódzki

\title{
Konflikty polityczne w przestrzeni publicznej i pamięci zbiorowej
}

DOI: 10.19195/1643-0328.22.3

Słowa kluczowe: konflikty polityczne, pamięć zbiorowa

\section{Wprowadzenie}

Nie sposób nie uznać za oczywistą konstatacji, iż problematyka konfliktów politycznych jest przedmiotem nie tylko nauk o polityce, ale także wielu innych dyscyplin humanistyczno-społecznych oraz wyodrębniających się coraz to nowych subdyscyplin i specjalności poznawczych. Z tego względu wyłącznie jednoznacznie i wąsko pojmowany politologiczny ogląd konfliktów, bez uwzględnienia eksplanacji socjologicznej, psychologicznej, kulturologicznej, historiozoficznej oraz aksjologicznej, zwłaszcza wymiaru etycznego, może być uznany za niezbyt satysfakcjonujący pod względem badawczym i poznawczym. Oznacza to, że etiologia konfliktów politycznych i ich następstw wymaga pogłębionego oglądu oraz wieloaspektowej eksplanacji, której może sprzyjać - o ile to jest niezbędne - uwzględnienie umiarkowanego podejścia interdyscyplinarnego ${ }^{1}$. Nie jest to bez znaczenia, jeśli chodzi o możliwości wyjaśniania istoty konfliktów politycznych, które mają wieloaspektowy wymiar społeczny ${ }^{2}$.

Wskazane jest zatem wielowymiarowe i jednocześnie pogłębione, a więc otwarte spojrzenie na etiologię postaci konfliktów. Stąd też za ze wszech miar użyteczne należy uznać analizowanie i wyjaśnianie poszczególnych konfliktów w kategoriach „studium

1 Zdarza się, iż uzasadniona merytorycznie interdyscyplinarność jest przesadnie eksponowana przez niektóre środowiska politologów, a przez inne totalnie kontestowana i potępiana. W następstwie tych tendencji odchodzi się od analizy i narracji politologicznej na rzecz swego rodzaju nieokreśloności metodologiczno-merytorycznej. Zob. szerzej: E. Ponczek, Możliwości i ograniczenia podejścia interdyscyplinarnego w politologicznych badaniach myśli politycznej i refleksji teoretyczno-politycznej, [w:] Międzynarodowe studia polityczne i kulturowe wobec wyzwań współczesności, red. T. Domański, Łódź 2016, s. 79-99.

2 Por. R.E. Babbie, Badania społeczne w praktyce, Warszawa 2007, passim; S. Juszczyk, Badania jakościowe w naukach społecznych. Szkice metodologiczne, Katowice 2013, passim. 
przypadku", jeśli chodzi o konkretne zdarzenia o znamionach konfliktowych, oraz poddanie ich analizie naukowej i w jej następstwie - wieloaspektowej eksplanacji nomologicznej ${ }^{3}$.

Uzyskane w tym zakresie uogólnienia pozwoliłyby na formułowanie syntetycznych konstatacji teoretycznych dotyczących proweniencji konfliktów, ich istoty oraz prawidłowości dotyczących ich trwania i ich wieloaspektowych następstw. Z tego względu niezbędny byłby wybór komparatywnego sposobu ich analizy i eksplanacji, nie tylko w układzie „poziomym”, a więc synchronicznym, ale także „pionowym”, z uwzględnieniem zmienności, co jest aksjomatem podejścia historycznego. Chodziłoby więc o otwarte i jednocześnie kreatywne podejście - na rzecz odkrycia i wyjaśnienia istoty konfliktów. Stąd też wskazany byłby wybór w miarę umiarkowanie interdyscyplinarnego podejścia do przedmiotu badań, którym są konflikty polityczne ${ }^{4}$.

\section{Możliwości i ograniczenia poznawcze etiologii konfliktów politycznych}

Od kilkudziesięciu lat w przestrzeni naukowej istnieją subdyscypliny naukowe, których przedmiotem badań w mniejszym lub większym stopniu są konflikty, jak chociażby konfliktologia (niem. Konfliktforschung) ${ }^{5}$ czy polemologia ${ }^{6}$ (rozwijana szczególnie we Francji). Są one rozumiane nie tylko jako nauki o konfliktach, ale również - co jest oczywiste $-\mathrm{o}$ wojnach. Chodzi przede wszystkim o refleksję poznawczą dotyczącą wszelakich konfliktów, niekoniecznie militarnych ${ }^{7}$.W szerszym kontekście refleksja nad konfliktami obejmuje także dokonania badawcze takich subdyscyplin, jak irenologia - znana $\mathrm{w}$ krajach nie tylko anglosaskich i skandynawskich jako peace research. Jej przedstawiciele uważają, że niezbędna jest refleksja nad tym wszystkim, co stanowi zaprzeczenie

${ }^{3}$ M. Strumińska-Kutra, I. Koładkiewicz, Studium przypadku, [w:] Badania jakościowe. Metody i narzędzia, red. D. Jemielniak, t. 2, Warszawa 2012.

${ }^{4}$ Por. E. Ponczek, op. cit., s. 79-99.

5 Zob. np. P. Dobrowolski, Friedensforschung w NRF. Organizacja i problemy badawcze, Katowice 1973, s. 5-21; S. Rudnik, Badania nad pokojem w Republice Federalnej Niemiec, Słupsk 1984, passim; P. Dobrowolski, Zachodnioniemieckie koncepcje odprężenia a Friedensordnung in Europa, Opole 1990, s. 32-49; W.K. Nowak, Badania nad pokojem w RFN, „Przegląd Stosunków Międzynarodowych” 1990, nr 5-6, s. 27-46; B. Mikulska-Góralska, Badania pokoju w Republice Federalnej Niemiec, [w:] Pokój w teorii i praktyce stosunków międzynarodowych, red. J. Kukułka, Warszawa 1991, s. 109-125.

6 Zob. np. J. Borgosz, Polemologia - „Przewrót kopernikański” w pojmowaniu wojny i pokoju?, „Studia Filozoficzne” 1983, nr 11-12, s. 105-119; idem, Polemologia, „Człowiek i Nauka”, Warszawa 1984/1985, s. 337-350; J. Świeca, Z metodologicznych rozważań nad przedmiotem i celem polemologii, „Zeszyty Naukowe Akademii Ekonomicznej w Katowicach” 1986, nr 103, s. 197-214; J. Bacik, Dzieje myśli polemologicznej w interpretacji Gastona Bouthoula, „Zeszyty Naukowe Wojskowej Akademii Politycznej” 1989, nr 4, s. 165172; J. Borgosz, Drogi i bezdroża filozofii pokoju (od Homera do Jana Pawła II), Warszawa 1989, s. 96-133, 221-251; por. F. Ryszka, Polityka i wojna. Świadomość potoczna a teorie XX wieku, Warszawa 1975, s. 23-30.

7 Por. K. Clausewitz, O wojnie, Warszawa 1928, s. 3-121; D. Schössler, Clausewitz, Lublin 1995, s. 96-133. 
pokoju w rozumieniu pozytywnym ${ }^{8}$. W tym ujęciu pokój jest uznawany za najwyższą wartość społeczną, dynamiczną, aczkolwiek nie statyczną. Z politologicznego „podejścia do pokoju wynika obowiązek systemowego widzenia związków między myśleniem i działaniem konsensualno-pokojowym a chronieniem i ulepszaniem globalnego środowiska człowieka" ". Rzecz w tym, aby doszło do wyeliminowania zarzewia konfliktu militarnego i działań terrorystycznych w skali masowej ${ }^{10}$. Za nader istotne należy uznać przedsięwzięcia badawcze w zakresie sekuritologii (security studies) ${ }^{11}$. Niezbędne okazuje się też wyjaśnienie istoty wieloaspektowego bezpieczeństwa, które na czas krótszy lub dłuższy uniemożliwia zaistnienie konfliktów ${ }^{12}$, spowodowanych również eskalacją terroryzmu w XXI stuleciu ${ }^{13}$.

Uwzględnienie tego rodzaju możliwości poznawczych przyczynia się nie tylko do poszerzenia i pogłębienia oglądu problematyki konfliktów politycznych, ale także kreatywnego zdyskontowania doświadczeń wyżej wyszczególnionych subdyscyplin w zakresie eksplanacji politologicznej kwestii, która jest w tym miejscu obiektem zainteresowania. Wiadomo, iż konflikty polityczne pojawiają się wtedy, gdy przez dłuższy czas uobecnia się „napięcie” w sferze stosunków społeczno-politycznych. Oznacza to permanentne trwanie „konfliktów ukrytych” o wieloaspektowych następstwach. Pojawia się wówczas ostry konflikt w zakresie relacji między rządzącymi i rządzonymi oraz między partiami

8 Znane są w literaturze irenologicznej dwa rozumienia słowa „pokój”, mianowicie „negatywne” i „pozytywne”, co uzasadnił w 1965 r. Norweg Johan Galtung. Pisali o tym w szerokim zakresie również polscy uczeni, jak Joachim Kondziela, Józef Kukułka i Waldemar Michowicz. Przyjmuje się, iż „pokój negatywny” oznacza „brak wojny”, a zatem bezpośredniego stosowania zorganizowanej przemocy kolektywnej wewnątrz państw i w stosunkach międzynarodowych. Z kolei „pokój pozytywny” równoznaczny jest z nieobecnością pośredniej „przemocy strukturalnej”, co umożliwia realizację humanistyczno-etycznych wartości społecznych. Zob. J. Kondziela, Badania nad pokojem. Teoria i jej zastosowanie, Warszawa 1974, s. 46-88, 144-157; J. Kukułka, Politologiczne podejście do pokoju, [w:] Pokój w teorii i praktyce stosunków międzynarodowych..., s. 9-22; W. Michowicz, Pokój jako przedmiot badań naukowych, „Zeszyty Naukowe Szkoły Wyższej im. Pawła Włodkowica” 7, 1998, s. 39-49.

9 J. Kukułka, op. cit., s. 11-14.

10 Por. S. Wojciechowski, „Sieć” przyczyn wspótczesnego terroryzmu - analiza czynników, mechanizmów i modeli, „Przegląd Polityczny” 2011, z. 3, s. 63-77.

11 Zob. R. Zięba, Nowe podejście do problematyki bezpieczeństwa, [w:] Bezpieczeństwo narodowe i międzynarodowe u schyłku XX wieku, red. D.B. Bobrow, E. Haliżak, R. Zięba, Warszawa 1997, s. 8-25; por. J. Świniarski, Wychowanie dla bezpieczeństwa personalnego i strukturalnego, [w:] Kształcenie i wychowanie w wojsku w toku przemian, red. Z. Markowski, R. Stępień, Warszawa 1994.

12 Por. R. Rosa, Filozofia bezpieczeństwa, Warszawa 1995, passim; idem, Filozofia i edukacja do bezpieczeństwa, Siedlce 1998, passim.

13 Zob. np. H. Münkler, Wojny naszych czasów, Kraków 2004, s. 7; R. Borkowski, Terroryzm ponowoczesny. Studium z antropologii polityki, Toruń 2006, s. 312, passim; J. Dworzecki, Terroryzm jako zagrożenie współczesnego świata, „Zeszyty Naukowe Apeiron”, Kraków 2011, passim; W. Dietl, K. Hirschmann, R. Tophoven, Terroryzm, Warszawa 2012, passim; Współczesne zagrożenia terroryzmem, red. K. Jałoszyński, Szczytno 2013, passim; W. Wojciechowski, Terroryzm na początku XXI wieku. Pojęcie - przejawy - przyczyny, Poznań 2013; A. Podraza, P. Potakowski, K. Wiak, Cyberterroryzm zagrożeniem XXI wieku, Warszawa 2014, passim; Bezpieczeństwo państwa a zagrożenie terroryzmem. Terroryzm na przełomie XX i XXI wieku, red. K. Jałoszyński, T. Aleksandrowicz, K. Wiciak, t. 1, Szczytno 2016, passim. 
politycznymi i różnymi lobbies. Znamienne jest, iż w przeszłości dochodziło oraz wciąż dochodzi w epoce współczesnej do konfliktów i wojen o różnej etiologii, którymi są nierzadko powstania narodowowyzwoleńcze, rewolucje, rozmaite rewolty i pucze. $\mathrm{W}$ ich następstwie inicjowane są kolejne konflikty, często ostre i trwałe, a więc - jak się wydaje - niemożliwe do neutralizacji.

Optymalnie wnikliwe spojrzenie na etiologię konfliktów pozwala na sformułowanie dość istotnej konstatacji: proweniencji konfliktów należy doszukiwać się w uwarunkowaniach nie tylko ekonomicznych i społecznych, ale również kulturowych i religijnych, a zwłaszcza cywilizacyjnych oraz także psychologicznych, aksjologicznych, etycznych, a nawet historiozoficznych ${ }^{14}$. Wiele o tym pisali teoretycy cywilizacji, tacy zwłaszcza jak chociażby: Oswald Spengler ${ }^{15}$, Arnold Toynbee ${ }^{16}$, Feliks Koneczny ${ }^{17}$, Samuel Huntington $^{18}$ czy Shmuel N. Eisenstadt ${ }^{19}$.

Biorąc pod uwagę to, co powiedziano wyżej, należy zauważyć, że etiologia konfliktów jest czymś nader złożonym i trudnym do wytłumaczenia, zwłaszcza jeśli uwzględni się wymiar realizacyjny. Oznacza to, że etiologia konfliktów wymaga koncentracji badawczej na wielu istotnych kwestiach ujmowanych wieloaspektowo, holistycznie i diachronicznie, co wymaga wnikliwej, a zatem pogłębionej eksplanacji poznawczej uwzględniającej w stosownym zakresie podejście interdyscyplinarne, gdy to jest niezbędne. Chodziłoby zatem o to, aby w zakresie badań naukowych i dociekań teoretycznych dotyczących konfliktów było aprobowane podejście otwarte i oryginalne, a zatem twórcze - czyli niesprowadzające się do bezrefleksyjnego mimetyzmu czy mimikry intelektualnej ${ }^{20}$.

Okazuje się, iż w procedurze dotyczącej rozpoznawania konfliktów politycznych, rozpatrywanych w kategoriach teorii polityki, niezbędne jest ich dogłębne wyjaśnienie $\mathrm{z}$ uwzględnieniem podejścia holistycznego i diachronicznego. W związku z tym wskazany byłby wybór opcji na rzecz multiparadygmatycznej formuły umożliwiającej rozpoznanie i wyjaśnienie istoty wszelakich konfliktów.

14 J. Topolski, Wojna jako przedmiot badań historycznych, [w:] Pax et bellum, red. K. Olejnik, Poznań 1993, s. 7-16.

15 O. Spengler, Zmierzch zachodu, Warszawa 2014, passim; idem, Człowiek i technika. Przyczynek do filozofii życia, Kraków 2014, passim.

16 A. Toynbee, Studium historii. Skrót dokonany przez D.C. Somervella, Warszawa 2000, passim.

17 Zob. np. F. Koneczny, O wielości cywilizacji, Komorów 2002, passim; idem, Prawa dziejowe, Komorów 2001, passim; idem, Napór Orientu na Zachód, Krzeszowice 2006, passim; idem, Obronić cywilizację łacińską, Lublin 2002, passim.

18 S. Huntington, Zderzenie cywilizacji, Warszawa 2008, passim.

19 S.N. Eisenstadt, Utopia i nowoczesność. Porównawcza analiza cywilizacji, Warszawa 2011, passim.

20 Por. A. Lobanowa, Mimikra społeczna w sferze nauki: treść i formy jej przejawiania się, „Zeszyty Naukowe Politechniki Śląskiej. Organizacja i Zarządzanie" 2014, z. 72, s. 115-123. 


\section{Ogląd konfliktów politycznych w kategoriach etycznych}

W procedurze eksplanacyjnej istoty konfliktów nie sposób abstrahować od wymiaru cywilizacyjno-kulturowego $\mathrm{i}-$ co jest oczywiste - aksjonormatywnego ${ }^{21}$. Analiza antyhumanistycznych realiów wojny oraz różnych postaci konfliktów sprzyjała refleksji krytycznej, umożliwiając ich etiologię w kategoriach etycznych, proponowaną przez wielu filozofów i ideologów w kwestii tworzenia wizji pokojowego ładu społeczno-polityczne$\mathrm{go}^{22}$. Jego realne zaistnienie miało zapewnić trwałe szczęście ludzkości, uniemożliwiając stosowanie przemocy personalnej i strukturalnej, która była często narzędziem państwa despotycznego, autorytarnego i totalitarnego ${ }^{23}$.

Może zadziwiać to, iż poglądy dotyczące przyczyn zachowań ekstremalnych wywołujących konflikt nie zawsze uzyskują jednoznaczną kwalifikację moralną pozwalającą na ukazanie ich optymalnie zobiektywizowanej wykładni poznawczej. Na co dzień można się często spotykać z moralną oceną zachowań konfliktowych odwołującą się do wykładni bądź opartej na podejściu relatywistycznym, bądź utrzymanej w duchu absolutyzmu etycznego ${ }^{24}$.

Ekstremiści i terroryści dość często twierdzą, że nie aprobują zła, ponieważ dążą do realizacji wzniosłych celów, w imię których uważają się oni za predestynowanych do stosowania przemocy bez ograniczeń. Toteż znamienną ich cechą jest skłonność do ujawniania fascynacji odnoszonej do relatywizmu moralnego, prowadzącego do permisywizmu etycznego ${ }^{25}$. Kierują się oni przeważnie fanatycznym dążeniem do realizacji zamierzonego celu w myśl formuły „im gorzej, tym lepiej”. Uznają to za coś niezbędnego, a nawet „konieczność dziejową”, jako że - ich zdaniem - niezbędne jest dążenie do bezalternatywnego urzeczywistniania określonej utopii zgodnie z makiawelistyczną formułą „cel uświęca środki”. Nie jest im obcy charakterystyczny sposób uzasadnienia swojego postępowania, bliski prymitywnemu relatywizmowi, w myśl którego odwołują się nierzadko do osobliwej „filozofii Kalego”. Toteż swego rodzaju „kalizm” - jako skrajny woluntarystyczny subiektywizm - jest niekiedy obecny w przestrzeni publicznej wielu państw, ponieważ bywa aprobowany przez różne kręgi klasy politycznej i decydentów ośrodka władzy. Nie bez znaczenia są w związku tym pejoratywne, a więc niehumanistyczne intencje, prowadzące do deprecjonowania powszechnie uznawanych nakazów

21 Z. Łyko, Etyczne wymiary polityki, [w:] Polityka a moralność, red. M. Szyszkowska, T. Kozłowski, Warszawa 2001, s. 11-16; por. J. Salij, Autonomia polityki i prawo moralne, „Znak” 1997, nr 7, s. 65-75; Z. Stawrowski, O niemoralności i moralności polityki, „Znak” 1998, nr 6, s. 3-42.

22 Zob. np. I. Kant, O wiecznym pokoju, Wrocław 1993, passim; por. M. Blaszke, Projekt wieczystego pokoju: de Sainte-Pierre, Rousseau, Kant, „Sofia” 2013, nr 13, s. 93-108.

23 Por. W. Theiss, O pedagogii totalitaryzmu, „Bobolanum” 8, 1997, s. 7-13.

24 Por. T. Zadykowicz, Moralna ocena terroryzmu w świetle jego przyczyn, „Collectanea Theologica” 73, 2003, nr 2, s. 110-124; M. Moskiewski, J. Socha, Terroryzm jako problem etyczny, „Studia Gdańskie” XVIIIXIX, 2005-2006, s. 35-64.

${ }^{25}$ Bardzo często przemoc przynosi ekstremistom i terrorystom zadowolenie i satysfakcję z czyjegoś nieszczęścia. Podatni są oni na aprobatę zawiści i nienawiści. Toteż opowiadają się za stosowaniem przemocy. Cechą zwolenników ekstremizmu i terroryzmu jest fascynacja relatywizmem moralnym. Zob. Nienawiść i zawiść, red. M. Szyszkowska, Warszawa 1989, passim. 
i zakazów moralnych oraz norm prawa stanowionego ${ }^{26}$. Z tego względu znamienne jest, iż stosowanie przemocy fizycznej i psychicznej wyraża się w zadowoleniu wielu osób z czyjegoś nieszczęścia (niem. Schadenfreude) ${ }^{27}$. Są one podatne na przyjmowanie postawy, która sprowadza się do aprobaty zawiści i nienawiści ${ }^{28}$. Bardzo często przemoc przynosi im satysfakcję i nieukrywaną radość.

W związku z powyższym nie sposób jest nie sformułować następujących pytań:

- W jakich okolicznościach uobecnia się tendencja umożliwiająca pojawienie się zła, którego następstwem jest konflikt?

- Kto komu i dlaczego czyni zło, wskutek czego dochodzi do konfliktu?29

- Czy zawsze brak czegoś, co określa się mianem dobra, powoduje pojawienie się zła? 30

- Czy cechą zachowań ekstremalnych jest „sama w sobie” fascynacja złem? ${ }^{31}$

- Czy konflikt jest wyłącznie następstwem emanacji zła?

- Czy w imię kierowania się wyobrażeniami co do potrzeby urzeczywistnienia jakiegoś dobra nie dochodzi do konfliktu?

- Czy pojawienie się konfliktów wynika z obniżonej wrażliwości etycznej oraz z niewiedzy i z nieumiejętności logicznego myślenia wielu przedstawicieli klasy politycznej?

- A może okazuje się to niekiedy rezultatem fascynacji nihilizmem etycznym pozwalającym na bezkrytyczną aprobatę permisywizmu, wykluczającego głębszą refleksję humanistyczno-etyczną?

- Czy może jest to następstwo egotycznego subiektywizmu o podłożu psychiczno-patologicznym?

Uzyskanie odpowiedzi na każde z tych pytań wymagałoby z pewnością pogłębionych badań, a zatem wieloaspektowej oraz wnikliwej eksplanacji różnego typu przypadków uobecniania się konfliktów. Nieuwzględnienie tego wymogu utrudniałoby pojawienie się pozytywnych możliwości w zakresie refleksji humanistyczno-etycznej w odniesieniu do istoty konfliktów i ich następstw. Mogłoby to grozić trywializacją problematyki konfliktów.

Przy uwzględnieniu wielu z powyższych pytań, a zwłaszcza tego ostatniego, wskazane byłoby wzięcie pod uwagę również podejścia psychologicznego ${ }^{32}$, w tym zwłaszcza psychoanalitycznego $^{33}$, a także oglądu w kategoriach „psychologii agresji”34 oraz stanowi-

26 S. Jedynak, Destruam et aedificabo. Studia z filozofii i myśli społecznej Zachodu, Lublin 1998, s. 291.

27 Zob. W. Sofsky, Traktat o przemocy, Wrocław 1999, s. 46-64, passim.

${ }^{28}$ Nienawiść i zawiść..., passim.

29 Zob. R. Safranski, Zło. Dramat wolności, Warszawa 1999, passim.

30 Zob. L. Wciórka, O filozoficznej problematyce zła, „Zeszyty Karmelickie” 1995, nr 3, s. 22-26.

31 Zob. M. Gołaszewska, Fascynacja złem. Eseje z teorii wartości, Warszawa-Kraków 1994, s. 63-200.

32 Por. S. Chełpa, T. Witkowski, Psychologia konfliktów. Praktyka radzenia sobie ze sporami, Warszawa 1995, s. 37-45.

33 Por. K. Pajor, Psychoanaliza Freuda po stu latach, Warszawa 2009, passim.

34 A. Frączak, Agresja interpersonalna: opis i analiza z perspektywy psychologii społecznej, [w:] Człowiek i agresja. Głosy o nienawiści i przemocy. Ujęcie interdyscyplinarne, red. Ł. Jurasz-Dudzik, Warszawa 2002, s. 42-55; M. Jarymowicz, Poszukiwania źródeł ludzkiej agresywności w wiedzy o ludzkich emocjach, [w:] Człowiek i agresja..., s. 173-187; P.P. Stępień, Genetyka agresji, [w:] Człowiek i agresja..., s. 34-42. 
ska zwolenników psychologicznej teorii „dezintegracji pozytywnej”35. Nie bez znaczenia byłyby starania na rzecz dogłębnej analizy specyficznych cech osobowości autorytar$n^{36}{ }^{36}$. Okazuje się bowiem, że skłonność do autorytaryzmu objawia się wrogością w relacjach międzygrupowych, zarówno w stosunku do obcych, jak i do swoich ${ }^{37}$. Pojawia się wówczas "język nienawiści”38.

Wskutek tego dochodzi do pojawienia się kolejnych sprzeczności i - co za tym idzie — stanu chronicznego konfliktu, który rodzi niejako „zapotrzebowanie na wrogów”39. Stymuluje to kształtowanie się atmosfery permanentnego stanu zagrożenia przenikniętego strachem egzystencjalnym. Często jest to związane z deficytem wszelkiego rodzaju dóbr, a zatem $z$ nierównym dostępem do nich, zarówno do tych rzeczowych, jak i aksjologicznych, którymi są wyższe wartości ${ }^{40}$. Wyznaczają one sens „pokoju pozytywnego”.

\section{Okoliczności sprzyjające mityzacji konfliktów politycznych o podłożu historycznym}

Konflikty nierzadko są pobudzane wskutek usilnego preferowania wielu odmiennych oglądów dawnej bądź bliższej przeszłości, a także odpowiednio dobranych wyjaśnień dotyczących ważnych aktualnie zdarzeń wyraźnie zakorzenionych w przeszłości. Następuje to również wówczas, gdy dochodzi do usilnego preferowania sprawczej roli społeczno-politycznej pewnych postaci historycznych, na ogół niejednoznacznie ocenianych i często kontrowersyjnych. Może to sprzyjać kreowaniu osobliwych mitów historyczno-politycznych, mniej lub bardziej wyraziście odzwierciedlanych w pamięci zbiorowej wielu społeczeństw oraz określonych klas i warstw społecznych, a także różnych populacji etnicznych ${ }^{41}$.

Taki lub inny stosunek do uobecniających się mitów historyczno-politycznych polaryzuje nader wyraźnie nastroje i emocje zbiorowe wielu grup społecznych. Prowadzi to do pojawiania się często niespodziewanych konfliktów, a także do mniej lub bardziej wyraźnej ich eskalacji. Nie jest to obojętne, jeśli chodzi o skłonność do uwzględniania rozlicznych opcji ideologiczno-politycznych oraz różnych aspektów ujawnianych poglądów w zakresie kształtujących się stosunków społeczno-politycznych w wielu krajach. Mogą one przerodzić się w konflikt względnie umiarkowany albo optymalnie zaostrzony, często długotrwały z małymi szansami na jego neutralizację i zanik. W następstwie

35 K. Dąbrowski, Dezintegracja pozytywna, Warszawa 1979, s. 29-30, passim.

36 Por. K. Korzeniowski, Autorytaryzm i jego psychopolityczne konsekwencje, [w:] Psychologia polityczna, red. K. Skarżyńska, Poznań 1999, s. 51-69.

37 J. Reykowski, Autorytaryzm i agresja wobec swoich i obcych, [w:] Człowiek i agresja..., s. 56-76.

38 Zob. S. Kowalski, M. Tulli, Zamiast procesu. Raport o mowie nienawiści, Warszawa 2003, passim; por. P. Zimbardo, Efekt Lucyfera. Dlaczego dobrzy ludzie czynia zło?, Warszawa 2008.

39 R.S. Robins, J.M. Post, Paranoja polityczna. Psychopatologia nienawiści, Warszawa 1999, s. 117-146.

40 R. Dahrendorf, Nowoczesny konflikt społeczny: esej o polityce wolności, Warszawa 1993, passim; por. M. Kłusak, Meandry polityki, Gdańsk 2005, s. 132-145.

41 Zob. M. Halbwachs, Collective memory, London 1978, s. 46-51. 
tego może dochodzić do pojawiania się nieprzewidywalnych następstw o znamionach zarówno negatywnych, jak i pozytywnych mitów i stereotypów. Zaczynają one stawać się stymulatorem sprzyjającym pojawianiu się głębszych i trwałych konfliktów, często bardzo trudnych do likwidacji ${ }^{42}$.

Nie sposób nie zwrócić uwagi na okoliczność, iż świadomość wielu klas i warstw społecznych mniej lub bardziej wyraziście cechuje zróżnicowanie preferencji społeczno-politycznych, odzwierciedlających się w pamięci zbiorowej ogółu obywateli takiego lub innego państwa. Okazuje się, że owe preferencje społeczno-polityczne cechuje mniejsze bądź większe zakorzenienie w historii, co sprzyja zróżnicowaniu pamięci o przeszłości, podlegającej w mniejszym bądź większym stopniu mityzacjii ${ }^{43}$. Staje się to nierzadko czynnikiem konfliktogennym uzewnętrzniającym się w przestrzeni politycznej.

$\mathrm{Z}$ tego względu nie można dziwić się, iż pojawiają się tendencje na rzecz wprowadzania do pamięci zbiorowej subiektywnie i - co jest oczywiste - woluntarystycznie preferowanych wyobrażeń, często sfalsyfikowanych, odnoszonych do dalszej i bliższej przeszłości ${ }^{44}$. Wskutek tego dochodzi często do negacji jej istotnych elementów, o czym niekiedy świadczy coś, co określa się mianem „pedagogiki wstydu” ${ }^{45}$. Wywołuje ona ambiwalentne odczucia i opinie uzewnętrzniające się w reakcji krytycznej o znamionach emocjonalno-woluntarystycznych w ramach dyskursu historyczno-politycznego.

Zdarza się, że ujawnianie postawy patriotycznej oraz aprobata tożsamości etniczno-narodowej i cywilizacyjnej uznawane bywają poniekąd za passé, a więc za coś przebrzmiałego, niemodnego, „nie na czasie” w epoce ponowoczesności. Stąd też zwolennicy

42 W. Nawrocki, Mity i stereotypy jako kulturowa legitymizacja uprzedzeń i agresji, [w:] Stereotypy i uprzedzenia. Uwarunkowania psychologiczne i kulturowe, red. A. Jasińska-Kania, M. Kofta, Warszawa 2001, passim.

43 Mityzację można rozpatrywać jako proces uzyskiwania przez bardziej lub mniej prawdziwy przekaz o przeszłości, a nawet teraźniejszości, bądź opinię o nich, atrybutów mitu, który staje się trwałym elementem pamięci zbiorowej. Jeżeli dochodzi do kształtowania się relatywnie podobnych czy też zbieżnych mitów, a zatem gdy zaczynają one stawać się względem siebie komplementarne, czyli koherentne, wówczas dochodzi do mitologizacji przeszłości. Zbiór tego rodzaju mitów powiązanych logicznie może uzyskać status np. mitologii narodowej, mitologii klasowej czy też warstwowej bądź mitologii religijnej albo ideologiczno-politycznej, opartej nierzadko na jakiejś gnozie o różnej proweniencji. Tego rodzaju mitologia może uzyskać relatywnie trwałą obecność w pamięci zbiorowej. Owa trwałość jest nader trudna do wyeliminowania, ponieważ podlega zakorzenieniu w sferze mentalnej jako aksjomat ludzkiego myślenia. Można zatem stwierdzić, iż mityzację, zwłaszcza polityczną — jako proces - określić można by mianem swego rodzaju „preludium” do mitologizacji przestrzeni publicznej. Por. inny pogląd: np. A. Sepkowski, Mity w wyjaśnianiu naukowym, [w:] Teoretyczne i metodologiczne wyzwania badań politologicznych $w$ Polsce, red. A. Antoszewski, A. Dumała, B. Kraus-Mozer, Lublin 2009, s. 85-100; idem, Człowiek w przestrzeni mitycznej, [w:] Mity historyczno-polityczne - wyobrażenia zbiorowe - polityka historyczna. Studia i materiały, red. E. Ponczek, A. Sepkowski, t. 1, Toruń, 2010, s. 25.

44 P.T. Kwiatkowski, Pamięć zbiorowa społeczeństwa polskiego w okresie transformacji, Warszawa 2008, s. 24-47, 220-439; idem, Czy lata III Rzeczypospolitej były „czasem pamięci”, [w:] Pamięć zbiorowa jako czynnik integracji i źródło konfliktów, red. A. Szpociński, Warszawa 2009, s. 125-166; P.T. Kwiatkowski et al., Między codziennościq a wielką historiq̨. Druga wojna światowa w pamięci zbiorowej społeczeństwa polskiego, Warszawa 2010, passim.

45 Zob. np. P. Siedlakowski, Pedagogika wstydu, „Echo Katolickie” 2014, nr 48. 
tego krytycznego stanowiska są skłonni do pejoratywnego epitetowania postaw patriotycznych oraz tożsamości zbiorowej o proweniencji etniczno-narodowej i cywilizacyjno-kulturowej ugruntowanej w pamięci o przeszłości. Nosicielom tej tożsamości insynuuje się, bez większych obiekcji, tendencje do uzewnętrzniania nastawienia ksenofobicznego, nacjonalistycznego, szowinistycznego, nieprzychylnego wobec jakiejkolwiek „inności”. Staje się to często źródłem nieporozumienia, wskutek czego dochodzi do błędnego utożsamiania patriotyzmu z nacjonalizmem czy nawet szowinizmem. Należy to uznać za objaw co najmniej nieprecyzyjności pod względem merytorycznym i semantycznym bądź za wyraz złej woli politycznej lub dążenia do manipulacji socjotechnicznej. Przejawia się to nader wyraźnie $\mathrm{w}$ trakcie walki o władzę polityczną, nie zawsze legitymizowaną w sposób zadowalający.

Ma to swoje osobliwe implikacje, jako że wpływa, z jednej strony, polaryzująco na relacje społeczne między rządzącymi i rządzonym, a, z drugiej strony, różnicuje stanowiska takich lub innych ugrupowań politycznych oraz grup nacisku, które kreują pożądane $\mathrm{z}$ własnego punktu widzenia postawy klasy politycznej uobecniające się wprost lub pośrednio. Owe dążenia stymulują w wymiarze wewnątrzpaństwowym stosunki między różnymi kręgami elit władzy i przywództwa politycznego wchodzącymi w skład klasy politycznej. Powoduje to nierzadko dezorientację w środowiskach zbiorowości rządzonych, co ujawnia podatność na demagogię oraz mniej lub bardziej świadomą recepcję haseł ochlokratyczno-populistycznych ${ }^{46}$.

Ze względu na uobecnienie się tego rodzaju tendencji mniej lub bardziej preferowana jest skłonność do mityzacji określonych elementów składowych pamięci zbiorowej. Doniosłą rolę mogą wówczas odgrywać przeciwstawne narracje o przeszłości wspomagane odpowiednio dobranymi mitami historyczno-politycznymi. Dochodzi do mityzacji pewnych postaci oraz zdarzeń i okoliczności, mniej lub bardziej sprzyjających sprawowaniu władzy „tu i teraz”, często uznanych wprost za dysfunkcjonalne względem realizowanych celów przez ośrodek decyzji politycznych ${ }^{47}$.

Decydenci polityczni związani z określonymi orientacjami ideologiczno-politycznymi, które utożsamiają się z wyborem odpowiednio dobranych elementów pamięci zbiorowej, są skłonni traktować przestrzeń publiczną instrumentalnie, jako miejsce uobecniania się takich lub innych mitów historyczno-politycznych, nierzadko pozornie atrakcyjnych w odbiorze społecznym. Stymuluje to tendencje do uobecniania się wyrazistych skłonności do manipulowania owymi mitami, co może sprzyjać pojawieniu się anomii społeczno-mentalnej bądź zantagonizowanej „atmosfery politycznej”48. Wskutek tego może dochodzić do nieprzewidywalnych zachowań społecznych, wyjaśnianych w kategoriach „psychologii tłumu”"49.

46 Por. E. Ponczek, Syndrom populizmu: trwałość - zmienność - następstwa, [w:] Populizm na przełomie XX i XXI wieku. Panaceum czy pułapka dla współczesnych społeczeństw?, red. M. Marczewska-Rytko, Toruń 2006, s. 65-77.

47 Por. Z.J. Pietraś, Decydowanie polityczne, Warszawa-Kraków 1998, s. 160 n.

48 Por. R.A. Dahl, B. Stinebrickner, Współczesna analiza polityczna, Warszawa 2007, s. 119-122.

49 G. Le Bon, Psychologia tłumu, Warszawa 2004, passim. 
Sprzyja to niewątpliwie eskalacji kryzysu politycznego przyczyniającego się do pojawiania się ostrego i wyraźnie pogłębiającego się — trudnego do zneutralizowania - konfliktu, którego genezę można dostrzegać w zróżnicowanym stosunku do uobecniających się przejawów pamięci zbiorowej, nader często podlegających falsyfikacji merytorycznej, a nawet wulgaryzacji interpretacyjnej. Objawia się to niekiedy w apologii lub negacji pewnych zdarzeń bądź postaci z przeszłości. Taka lub inna reakcja na te skłonności i zjawiska może sprzyjać pojawieniu się okoliczności charakteryzujących się dążeniem do dalszej stymulacji i pogłębienia relacji konfliktogennych, które w mniejszym lub większym stopniu mogą uobecniać się $\mathrm{w}$ przestrzeni publicznej. W następstwie tego może dojść do preferowania dążenia stymulującego atmosferę wyznaczoną sentencjami homo homini lupus est $t^{50}$ oraz bellum omnium contra omnes ${ }^{51}$. Skutkiem tego może być pojawienie się chaosu mentalnego i w jego następstwie anomii społecznej, co jest bardzo niebezpieczne w sferze stosunków politycznych, także w wymiarze międzynarodowym.

Jednocześnie może pojawić się dążenie do preferowania polityki pamięci o charakterze konsensualnym w myśl sentencji homo homini amicus est ${ }^{52}$. Może temu towarzyszyć pragnienie osiągnięcia porozumienia międzynarodowego na rzecz zaistnienia bezpieczeństwa geopolitycznego, uznawanego za niezbywalny wymóg racji stanu ${ }^{53}$.

\section{Wielość polityk pamięci a możliwość eskalacji lub zaniku konfliktów politycznych}

Zdarza się, iż w pamięci zbiorowej uobecniają się obszary, której części składowe cechuje mniej lub bardziej wyraźne zrutynizowanie i niekiedy sfalsyfikowanie, a także zmityzowanie. Nie jest to obojętne, jeśli chodzi o kształtowanie się sfery wyobrażeń zbiorowych i indywidualnych, dotyczących dawnej, czy też bliższej, przeszłości. Owe wyobrażenia mogą stymulować tendencje do oddziaływań o następstwach konfliktogennych, przejawiających się w przewidywalnych bądź nieprzewidywalnych zachowaniach różnych kręgów klasy politycznej, jak również w postawach poszczególnych zbiorowości społeczeństwa.

50 Plautus Makcjusz, rzymski poeta, komediopisarz, autor Jeńców - sztuki o wojnach punickich, starał się wyjaśnić przyczyny wojen między ludźmi. Doszedł on do wniosku, że źródłem wszelkich walk i wojen jest natura człowieka, a więc jego cechy biologiczne. Plautus uważany jest za wyraziciela słynnej sentencji homo homini lupus est, co przedstawił w komedii Asinaria. Zob. M. Plaut, Osły. Misa pełna złota, [w:] Plaut, Komedie, t. II, Warszawa [2003]; por. J. Borgosz, Drogi i bezdroża filozofii pokoju..., s. 52.

51 Zob. T. Hobbes, Lewiatan, czyli materia, forma i władza państwa kościelnego i świeckiego, Warszawa 2005, passim.

52 Por. I. Italo, Cycerońska koncepcja pokoju, „Przegląd Humanistyczny” 1990, nr 7, s. 133-141.

53 Zob. F. Znaniecki, Kult państwa, [w:] Polska myśl demokratyczna w ciagu wieków. Antologia, red. M. Kridl et al., Warszawa 1986, s. 300-301; por. E. Ponczek, Aksjologiczny wymiar polskiej racji stanu: Od demokracji szlacheckiej do demokracji liberalnej, [w:] Demokracja - liberalizm - społeczeństwo obywatelskie. Doktryna i myśl polityczna, red. W. Kaute, P. Świercz, Katowice 2004, s. 405-423. 
Decydenci usytuowani w ośrodku władzy często aprobują oportunistyczne wzory zachowań, które w ich mniemaniu przynosić mają pożądany efekt w relatywnie krótkim odcinku czasowym. Jednakże w dłuższej perspektywie czasowej rodzi to nierzadko negatywne następstwa społeczne i wskutek tego może dochodzić do zaistnienia okoliczności niesprzyjających neutralizacji konfliktu politycznego. Pozytywne rozwiązanie tego rodzaju sytuacji może nastąpić pod warunkiem adekwatnego wyjaśnienia przyczyn i okoliczności uobecniania się konfliktów zachodzących w strukturze systemu politycznego. W związku z tym niezbędny jest holistyczny i diachroniczny ogląd konfliktu, umożliwiający wieloaspektowe wyjaśnienie jego przyczyn. Sprzyjałoby to znalezieniu antidotum na zaistniałe konflikty ${ }^{54}$.

W tego rodzaju osobliwych sytuacjach mogą objawiać się w mniejszym lub większym stopniu tendencje do absolutyzacji określonych aksjomatów społeczno-politycznych, które zaczynają w odpowiednich okolicznościach służyć uzasadnianiu „jedynie słusznych" wykładni zapisów normatywnych, a także przyjętych sposobów postępowania politycznego. Owe tendencje mogą sprzyjać eksponowaniu pamięci o subiektywnie dobranych zdarzeniach, bardziej dawnych bądź niedawnych, co sprzyja ich mityzacji politycznej. Wskutek tego zaczynają uobecniać się najpierw ukryte, a z czasem jawne sprzeczności między rządzącymi a rządzonymi oraz między poszczególnymi państwami. Może także dojść do pojawienia się sprzeczności między społeczeństwami utożsamiającymi się z określonymi cywilizacjami, co sprzyja niekiedy zaistnieniu konfliktu kulturowo-politycznego o znamionach trwałości w krótszym lub dłuższym odcinku czasowym. Znamienne jest to, iż od ponad 20 lat mówi się o zagrożeniu, jakim byłoby zderzenie cywilizacji, co nie jest bynajmniej metaforą ideologiczno-polityczną ${ }^{55}$.

Preferowanie w sposób rygorystyczny takich lub innych zmityzowanych ustaleń dotyczących dawnej i niedawnej przeszłości oraz subiektywnych mniemań o niej może prowadzić do swego rodzaju „usztywnienia” stanowisk i - w ich następstwie - do polaryzacji wpływającej na kształtowanie się mniej lub bardziej pogłębionego konfliktu. Zaistnienie takiego stanu rzeczy nie pozwala na prowadzenie dialogu umożliwiającego osiągnięcie satysfakcjonującego konsensusu społeczno-politycznego. Pojawiają się zatem przeciwstawne opinie dotyczące teraźniejszości i przeszłości, zwłaszcza w tych kwestiach, co do których można „pięknie się różnić”, o czym pisał Cyprian Kamil Norwid ${ }^{56}$. Mogą wówczas uobecniać się postawy i poglądy uznane za nie w pełni propaństwowe, czy też kolidujące $\mathrm{z}$ prawem, bądź sprzeczne $\mathrm{z}$ aktualnym paradygmatem etycznym albo niezgodne z punktu widzenia osób określających interes i teleologię społeczną ośrodka władzy politycznej, mającego taką lub inną proweniencję oraz określony poziom mocy legitymizacyjnej ${ }^{57}$.

54 Por. R.A. Dahl, B. Stinebrickner, op. cit., s. 119-122.

55 S. Huntington, op. cit.

56 Zob. C.K. Norwid, Promethidion. Rzecz o dwóch dialogach z epilogiem, Wrocław 1995. Ów polski poeta romantyczny napisał: „Umiemy się tylko kłócić albo kochać, ale nie umiemy się różnić pięknie i mocno”. Myśl jest nadal aktualna, ponieważ odmienne poglądy polityczne mogą zdecydowanie i trwale poróżnić ludzi.

57 Por. A. Czajowski, Legitymacja władzy państwowej a legitymacja polityczna do jej pełnienia, [w:] Prawowitość czy zgodność z prawem? Legitymacja władzy w państwie demokratycznym, red. A. Preisner, Wrocław 2010. 
W związku z tym nie bez znaczenia jest odwoływanie się do pewnych ważnych postaci historycznych oraz do mniej lub bardziej spolaryzowanych i pojmowanych subiektywnie określonych odniesień z przeszłości, podlegających procesowi wartościowania. Uzyskują one stosowne odzwierciedlenie w pamięci zbiorowej takich lub innych społeczności aspirujących do preferowania swojej podmiotowości w wymiarze umiarkowanym bądź nadmiernym ${ }^{58}$.

Okazuje się, iż wzory w zakresie sprawowania władzy mogą ulegać eskalującej petryfikacji wskutek ich wcześniejszej schematyzacji, rutynizacji i mityzacji. Może to także uobecnić się w procedurze podejmowania określonych decyzji, często nietrafnych, oraz wskutek ich wadliwej implementacji. W następstwie tego mogą uobecniać się tendencje do prowadzenia konfliktogennej polityki pamięci versus polityki historycznej, bez możliwości uzewnętrznienia się pluralistycznych odniesień do przeszłości, mogących uzyskiwać stosowne odzwierciedlenie w pamięci zbiorowej ${ }^{59}$.

Wskutek zaistnienia powyższych okoliczności może dochodzić: po pierwsze, do absolutyzacji, dość często pojmowanego egoistycznie, własnego stanowiska przez establishment polityczny, a po drugie - do nihilizacji zbiorowego interesu społecznego, prowadzącego w określonych sytuacjach do pojawienia się anomii społecznej, u której podstaw znajdują się „ukryte konflikty”. Sprzyja to erozji procesu sprawowania władzy i przyczynia się do osłabienia potencjału legitymizacyjnego ośrodka decyzji politycznych. Zaczyna to prowadzić do daleko idącej delegitymizacji przywództwa politycznego i do destrukcji ośrodka decyzyjnego w zakresie możliwości sprawowania władzy. Nihilizacji legitymizacyjnej sprzyja nierzadko jednostronna i jednocześnie uproszczona oraz schematyczna mityzacja wielu faktów politycznych oraz okoliczności ich uobecniania się. Niemniej jednak tendencja do epatowania nadmierną mityzacją bywa niekiedy dyskretnie neutralizowana albo zdecydowanie kwestionowana w okolicznościach pojawienia się czegoś osobliwego i nieznanego wywołującego dysonans polityczny. Może także pojawić się znamienne zjawisko mityzacji à rebours, co w dogodnych okolicznościach zaczyna stawać się zarzewiem kolejnego konfliktu ${ }^{60}$.

Nie sposób jest zatem nie doceniać potrzeby liczenia się z emanującymi osobliwościami mityzacyjnymi w sferze świadomości społecznej. Z tego względu dochodzi w mniejszym bądź większym stopniu do uobecnienia się określonych odniesień do przeszłości w pamięci zbiorowej, a zwłaszcza mitów historyczno-politycznych, co może stymulować nieoczekiwane pojawienie się reakcji ze strony zarówno rządzonych, jak i rządzących. Zdarza się, iż politycy eksponują w sposób nazbyt pewny siebie przeświadczenie, iż są w stanie „panować” nad przestrzenią polityczną i pamięcią zbiorową, co ma oznaczać, że ją wystarczająco kontrolują, a także dyskontują w imię urzeczywistnienia własnych celów, nie licząc się jednak z ich następstwami konfliktogennymi. Okazuje się, że wiele zachowań społecznych i związanych z nimi zdarzeń politycznych może co najmniej

58 Por. Podmiotowość i tożsamość, red. J. Migasiński, Warszawa 2001, passim,

59 Zob. M. Halbwachs, Społeczne ramy pamięci, Warszawa 2008, s. 421-432; por. B. Szacka, Czas przeszły. Pamięć. Mit, Warszawa 2006, s. 34.

60 Zob. E. Ponczek, Od metaforycznej polityzacji pamięci zbiorowej do refleksji teoretycznej dotyczacej polityki historycznej, „Studia Politologiczne” 37, 2015, s. 191-218. 
zadziwiać, a nierzadko nawet okazać się „niespodzianką” dla decydentów ze względu na niedocenianie przez nich imponderabiliów mityzacyjnych. Mogą one uobecniać się w mniejszym lub większym stopniu - aczkolwiek także nieoczekiwanie - w pamięci zbiorowej zarówno elity władzy, jak i całej klasy politycznej, a także ogółu obywateli państwa czy nawet szerszej społeczności globalnej.

Sprzyja to w odpowiednich okolicznościach pojawieniu się mitów historyczno-politycznych, którymi mogą w sposób instrumentalny posługiwać się różni kreatorzy takiej lub innej polityki pamięci versus polityki historycznej ${ }^{61}$, także $\mathrm{w}$ skali międzynarodowej ${ }^{62}$. Wyrażają oni nadzieję, iż uda im się zmobilizować poszczególne zbiorowości społeczne na rzecz zachowań prowadzących do skutecznej aktywności politycznej. Wskutek tego takie lub inne zbiorowości zaczynają dążyć do optymalnego upodmiotowienia społeczno-politycznego. Może temu służyć poszukiwanie stosownych odniesień do pamięci grupowej lub ogólnonarodowej, czy też cywilizacyjno-kulturowej w wymiarze globalnym, co nierzadko może przyczyniać się do urzeczywistnienia celów o znamionach prospołecznych albo interesów o intencjach egoistycznych. W następstwie tego mogą w przestrzeni publicznej uobecniać się opcje uwzględniające konsensualną bądź konfliktową politykę pamięci ${ }^{63}$.

Tak też mity historyczno-polityczne określające specyfikę pamięci zbiorowej zaczynają stawać się czynnikiem konfliktogennym w sferze relacji intergrupowych wielu społeczeństw obywatelskich. Z tego względu nie można jednak wykluczyć ewentualności zaistnienia jakiejś nieznanej i osobliwej przemocy i wskutek tego erupcji jakiegoś konfliktu w wymiarze globalnym ${ }^{64}$.

\section{Refleksja końcowa}

Analityczne oraz wieloaspektowe i - tym samym - optymalnie wnikliwe pod względem nomologicznym spojrzenie na etiologię konfliktów politycznych pozwala na sformułowanie kilku istotnych konstatacji o znamionach hipotetycznych.

Proweniencji konfliktów można doszukiwać się w uwarunkowaniach nie tylko ekonomicznych, ale również kulturowo-społecznych, zwłaszcza cywilizacyjnych, religijnych, aksjologicznych, w tym etycznych oraz historiozoficznych. $\mathrm{Z}$ tego względu konfliktami

61 Por. E. Ponczek, Polityka wobec pamięci versus polityka historyczna: aspekty semantyczny, aksjologiczny i merytoryczny w narracji polskiej, „Przegląd Politologiczny” 2013, nr 2, s. 7.

62 Zob. E. Ponczek, Polityka historyczna w stosunkach międzynarodowych i ich ogląd z perspektywy polskiej, [w:] Mechanika sceny międzynarodowej. Nowe wyzwania w nowej epoce, red. I. Kraś, B. Matsili, M. Soja, Częstochowa 2013, s. 307-321; idem, Polityka historyczna a geopolityczny wymiar bezpieczeństwa (ogląd z perspektywy polskiej), [w:] Bezpieczeństwo we wspótczesnej myśli politycznej, red. M. Fałdowska, A. Wielomski, Warszawa 2015, s. 171-194.

63 Por. E. Ponczek, Polityka historyczna w Polsce - od ogladu retrospektywnego do refleksji o następstwach przyszłościowych, [w:] Narracje pamięci: między polityka a historia, red. K. Kącka, J. Piechowiak-Lamparska, A. Ratke-Majewska, Toruń 2015, s. 29-57.

64 Zob. R. Dahrendorf, op. cit., passim; por. J.R. Sielezin, Teoretyczne problemy konfliktów społeczno-politycznych i ich specyfika. Próba egzemplifikacji, „Wrocławskie Studia Politologiczne” 2010, nr 11, s. 64-80. 
mogą zajmować się w wymiarze poznawczym liczni specjaliści nauk humanistyczno-społecznych, pragnący wyjaśnić ich istotę, uwzględniający wielorakie implikacje aksjologiczno-etyczne, psychologiczne i historyczne.

Konflikty mogą być stymulowane wskutek uobecniania się różnych, często skrajnych, oglądów i wyjaśnień teraźniejszości mniej lub bardziej zakorzenionych w osobliwościach historycznych przeszłości dawnej, czy też bliższej, zwłaszcza gdy pojawia się tendencja do preferowania sprawczej roli odpowiednio dobranych bohaterów - nierzadko kontrowersyjnych, często w okolicznościach kształtowania osobliwych mitów albo „antymitów" (czyli mitów à rebours) historyczno-politycznych rozszerzających się przestrzennie i przekazywanych współczesnym pokoleniom oraz kolejnym generacjom społecznym.

Stosunek do takich lub innych mitów historyczno-politycznych może w sposób znaczący polaryzować nastroje w społeczeństwie i wskutek tego prowadzić do pojawiania się konfliktów oraz ich eskalacji. Zaczyna to sprzyjać zaistnieniu nieprzewidywalnych i negatywnych następstw, których nawet najbardziej wnikliwy „strateg” polityczny, czy też politolog o skłonnościach do kreowania rozmaitych prospekcji społecznych bądź uczony prognozolog lub futurolog - nie są w stanie przewidzieć.

Z tego względu może pojawić się przeświadczenie, iż nie należy „żyć przeszłością”, a nawet trzeba o niej zapomnieć, jako że „posługiwanie się" historią w polityce staje się nader niebezpieczne, czy też staje się przysłowiową „kulą u nogi” teraźniejszości65. Tego rodzaju pogląd może prowadzić do zanegowania tego, co określa się jako polityka pamięci versus polityka historyczna. Niezależnie od pojawiania się tendencji do głoszenia tego rodzaju poglądu potrzebne jest jednak stworzenie możliwości docenienia imponderabiliów historiozoficznych oraz wyobrażeń odnoszonych do dziejów ludzkości i cywilizacji uobecniających się w pamięci zbiorowej takiego lub innego społeczeństwa. Może to pozwolić politologom dostrzec istotę i rolę sprawczej polityki pamięci - jako bytu politycznego - i jego wielorakich funkcji społecznych w szeroko rozumianej przestrzeni publicznej, która jest miejscem pojawiania się konfliktów.

\section{Bibliografia}

Babbie E., Badania społeczne w praktyce, Wydawnictwo Naukowe PWN, Warszawa 2007.

Bacik J., Dzieje myśli polemologicznej w interpretacji Gastona Bouthoula, „Zeszyty Naukowe Wojskowej Akademii Politycznej" 1989, nr 4.

Bezpieczeństwo państwa a zagrożenie terroryzmem. Terroryzm na przełomie XX i XXI wieku, red. K. Jałoszyński, K. Wiciak, Wydawnictwo Wyższej Szkoły Policji w Szczytnie, Szczytno 2013.

Bezpieczeństwo państwa a zagrożenie terroryzmem. Terroryzm na przełomie XX i XXI wieku, red. K. Jałoszyński, K. Wiciak, t. 1, Wydawnictwo Wyższej Szkoły Policji w Szczytnie, Szczytno 2016.

Blaszke M., Projekt wieczystego pokoju: de Sainte-Pierre, Rousseau, Kant, „Sofia” 2013, nr 13.

Borgosz J., Drogi i bezdroża filozofii pokoju (od Homera do Jana Pawła II), Wydawnictwo Ministerstwa Obrony Narodowej, Warszawa 1989.

Borgosz J., Polemologia, „Człowiek i Nauka”, Warszawa 1984/1985.

${ }^{65}$ Por np. E. Ponczek, Z myślą o integralnej refleksji teoretycznej w kwestii polityki historycznej, [w:] Czym jest teoria w politologii?, red. Z. Blok, Warszawa 2011, s. 264-266. 
Borgosz J., Polemologia — „Przewrót kopernikański” w pojmowaniu wojny i pokoju?, „Studia Filozoficzne” 1983, nr 11-12.

Borkowski R., Terroryzm ponowoczesny. Studium z antropologii polityki, Wydawnictwo Adam Marszałek, Toruń 2006.

Chełpa S., Witkowski T., Psychologia konfliktów. Praktyka radzenia sobie ze sporami, Wydawnictwo Szkolne i Pedagogiczne, Warszawa 1995.

Clausewitz K., O wojnie, Państwowy Instytut Naukowo-Wydawniczy, Warszawa 1928.

Czajowski A., Legitymacja władzy państwowej a legitymacja polityczna do jej petnienia, [w:] Prawowitość czy zgodność z prawem? Legitymacja władzy w państwie demokratycznym, red. A. Preisner, Wydawnictwo Beta-Druk, Wrocław 2010.

Dahl R.A., Stinebrickner B., Współczesna analiza polityczna, Wydawnictwo Naukowe Scholar, Warszawa 2007.

Dahrendorf R., Nowoczesny konflikt społeczny. Esej o polityce wolności, Czytelnik, Warszawa 1993.

Dąbrowski K., Dezintegracja pozytywna, Państwowy Instytut Wydawniczy, Warszawa 1979.

Dietl W., Hirschmann K., Tophoven R., Terroryzm, Wydawnictwo Naukowe PWN, Warszawa 2012.

Dobrowolski P., Friedensforschung w NRF. Organizacja i problemy badawcze, Wydawnictwo Śląskiego Instytutu Naukowego w Katowicach, Katowice 1973.

Dobrowolski P., Zachodnioniemieckie koncepcje odprężenia a Friedensordnung in Europa, Wydawnictwo Śląskiego Instytutu Naukowego w Opolu, Opole 1990.

Dworzecki J., Terroryzm jako zagrożenie współczesnego świata, „Zeszyty Naukowe Apeiron”, Kraków 2011.

Eisenstadt S.N., Utopia i nowoczesność. Porównawcza analiza cywilizacji, Wydawnictwo Oficyna Naukowa, Warszawa 2011.

Frączak A., Agresja interpersonalna: opis i analiza z perspektywy psychologii społecznej, [w:] Człowiek i agresja. Głosy o nienawiści i przemocy. Ujęcie interdyscyplinarne, red. Ł. Jurasz-Dudzik, Wydawnictwo Sic!, Warszawa 2002.

Gołaszewska M., Fascynacja złem. Eseje z teorii wartości, Wydawnictwo Naukowe PWN, Warszawa-Kraków 1994.

Halbwachs M., Collective Memory, University of London Press, London 1978.

Halbwachs M., Społeczne ramy pamięci, Wydawnictwo Naukowe PWN, Warszawa 2008.

Hobbes T., Lewiatan, czyli materia, forma i władza państwa kościelnego i świeckiego, Wydawnictwo Fundacji ENETHEA, Warszawa 2005.

Huntington S., Zderzenie cywilizacji, Wydawnictwo Muza S.A., Warszawa 2008.

Jarymowicz M., Poszukiwania źródeł ludzkiej agresywności w wiedzy o ludzkich emocjach, [w:] Człowiek i agresja. Głosy o nienawiści i przemocy. Ujęcie interdyscyplinarne, red. Ł. Jurasz-Dudzik, Wydawnictwo Sic!, Warszawa 2002.

Jedynak J., Destruam et aedificabo. Studia z filozofii i myśli społecznej Zachodu, Wydawnictwo Uniwersytetu Marii Curie-Skłodowskiej, Lublin 1998.

Juszczyk S., Badania jakościowe w naukach społecznych. Szkice metodologiczne, Wydawnictwo Uniwersytetu Śląskiego, Katowice 2013.

Kant I., O wiecznym pokoju, Wydawnictwo Uniwersytetu Wrocławskiego, Wrocław 1993.

Kłusak M., Meandry polityki, Wydawnictwo Uniwersytetu Gdańskiego, Gdańsk 2005.

Kondziela J., Badania nad pokojem. Teoria i jej zastosowanie, Wydawnictwo Ośrodka Dokumentacji i Studiów Społecznych, Warszawa 1974.

Koneczny F., Napór Orientu na Zachód, Dom Wydawniczy Ostoja, Krzeszowice 2006.

Koneczny F., O wielości cywilizacji, Wydawnictwo Antyk, Komorów 2002.

Koneczny F., Obronić cywilizację łacińską, Wydawnictwo Fundacji Rozwoju i Kultury Polskiej, Lublin 2002.

Koneczny F., Prawa dziejowe, Wydawnictwo Antyk, Komorów 2001.

Korzeniowski K., Autorytaryzm i jego psychopolityczne konsekwencje, [w:] Psychologia polityczna, red. K. Skarżyńska, Wydawnictwo Zysk i S-ka, Poznań 1999.

Kowalski S., Tulli M., Zamiast procesu. Raport o mowie nienawiści, Wydawnictwo W.A.B., Warszawa 2003. 
Kukułka J., Politologiczne podejście do pokoju, [w:] Pokój w teorii i praktyce stosunków międzynarodowych, red. idem, Wydawnictwo Uniwersytetu Gdańskiego, Warszawa 1991.

Kwiatkowski P.T., Czy lata III Rzeczypospolitej byty „czasem pamięci”, [w:] Pamięć zbiorowa jako czynnik integracji i źródło konfliktów, red. A. Szpociński, Wydawnictwo Naukowe Scholar, Warszawa 2009.

Kwiatkowski P.T., Pamięć zbiorowa społeczeństwa polskiego w okresie transformacji, Wydawnictwo Naukowe Scholar, Warszawa 2008.

Kwiatkowski P.T. et al., Między codziennościq a wielką historiq. Druga wojna światowa w pamięci zbiorowej społeczeństwa polskiego, Wydawnictwo Naukowe Scholar, Warszawa 2010.

Le Bon G., Psychologia tłumu, Wydawnictwo Antyk, Warszawa 2004.

Lobanowa A., Mimikra społeczna w sferze nauki: treść i formy jej przejawiania się, „Zeszyty Naukowe Politechniki Śląskiej. Organizacja i Zarządzanie" 2014.

Łyko Z., Etyczne wymiary polityki, [w:] Polityka a moralność, red. M. Szyszkowska, T. Kozłowski, Wydawnictwo Naukowe PWN, Warszawa 2001.

Michowicz W., Pokój jako przedmiot badań naukowych, „Zeszyty Naukowe Szkoły Wyższej im. Pawła Włodkowica" 7, Płock 1998.

Mikulska-Góralska B., Badania pokoju w Republice Federalnej Niemiec, [w:] Pokój w teorii i praktyce stosunków międzynarodowych, red. J. Kukułka, Wydawnictwo Uniwersytetu Gdańskiego, Warszawa 1991.

Moskiewski M., Socha J., Terroryzm jako problem etyczny, „Studia Gdańskie” XVIII-XIX, 2005-2006.

Münkler H., Wojny naszych czasów, Wydawnictwo WAM, Kraków 2004.

Nawrocki W., Mity i stereotypy jako kulturowa legitymizacja uprzedzeń i agresji, [w:] Stereotypy i uprzedzenia. Uwarunkowania psychologiczne i kulturowe, red. A. Jasińska-Kania, M. Kofta, Wydawnictwo Scholar, Warszawa 2001.

Nienawiść i zawiść, red. M. Szyszkowska, Instytut Wydawniczy Związków Zawodowych, Warszawa 1989.

Norwid C.K., Promethidion. Rzecz o dwóch dialogach z epilogiem, Wydawnictwo Ossolineum, Wrocław 1995.

Nowak W.K., Badania nad pokojem w RFN, „Przegląd Stosunków Międzynarodowych” 1990, nr 5-6.

Pajor K., Psychoanaliza Freuda po stu latach, Wydawnictwo Fundacji ENETHEA, Warszawa 2009.

Pietraś Z.J., Decydowanie polityczne, Wydawnictwo Naukowe PWN, Warszawa-Kraków 1998.

Plaut M., Osły. Misa petna złota, [w:] Plaut, Komedie, t. II, Wydawnictwo Prószyński i S-ka, Warszawa [2003].

Podmiotowość i tożsamość, red. J. Migasiński, Wydawnictwo Wydziału Filozofii i Socjologii Uniwersytetu Warszawskiego, Warszawa 2001.

Podraza A., Potakowski P., Wiak K., Cyberterroryzm zagrożeniem XXI wieku, Wydawnictwo Delfin, Warszawa 2014.

Ponczek E., Aksjologiczny wymiar polskiej racji stanu: Od demokracji szlacheckiej do demokracji liberalnej, [w:] Demokracja - liberalizm - społeczeństwo obywatelskie. Doktryna i myśl polityczna, red. W. Kaute, P. Świercz, Wydawnictwo Uniwersytetu Śląskiego, Katowice 2004.

Ponczek E., Możliwości i ograniczenia podejścia interdyscyplinarnego w politologicznych badaniach myśli politycznej i refleksji teoretyczno-politycznej, [w:] Międzynarodowe studia polityczne i kulturowe wobec wyzwań współczesności, red. T. Domański, Wydawnictwo Uniwersytetu Łódzkiego, Łódź 2016.

Ponczek E., Od metaforycznej polityzacji pamięci zbiorowej do refleksji teoretycznej dotyczącej polityki historycznej, „Studia Politologiczne” 37, 2015.

Ponczek E., Polityka historyczna a geopolityczny wymiar bezpieczeństwa (ogląd z perspektywy polskiej), [w:] Bezpieczeństwo we wspótczesnej myśli politycznej, red. M. Fałdowska, A. Wielomski, Wydawnictwo von Borowiecky, Warszawa 2015, s. 171-194.

Ponczek E., Polityka historyczna w Polsce - od ogladu retrospektywnego do refleksji o następstwach przyszłościowych, [w:] Narracje pamięci: między polityka a historią, red. K. Kącka, J. Piechowiak-Lamparska, A. Ratke-Majewska, Wydawnictwo Uniwersytetu Mikołaja Kopernika, Toruń 2015.

Ponczek E., Polityka historyczna $w$ stosunkach międzynarodowych $i$ ich ogląd z perspektywy polskiej, [w:] Mechanika sceny międzynarodowej. Nowe wyzwania w nowej epoce, red. I. Kraś, B. Matsili, M. Soja, Wydawnictwo Akademii Jana Długosza, Częstochowa 2013, s. 307-321. 
Ponczek E., Polityka wobec pamięci versus polityka historyczna: aspekty semantyczny, aksjologiczny i merytoryczny w narracji polskiej, „Przegląd Politologiczny” 2013, nr 2.

Ponczek E., Syndrom populizmu: trwałość - zmienność - następstwa, [w:] Populizm na przełomie XX i XXI wieku. Panaceum czy pułapka dla wspótczesnych społeczeństw?, red. M. Marczewska-Rytko, Wydawnictwo Adam Marszałek, Toruń 2006.

Ponczek E., Z myśla o integralnej refleksji teoretycznej w kwestii polityki historycznej, [w:] Czym jest teoria w politologii?, red. Z. Blok, Dom Wydawniczy ELIPSA, Warszawa 2011.

Reykowski J., Autorytaryzm i agresja wobec swoich i obcych, [w:] Człowiek i agresja. Głosy o nienawiści i przemocy. Ujęcie interdyscyplinarne, red. Ł. Jurasz-Dudzik, Wydawnictwo Sic!, Warszawa 2002.

Robins R.S., Post J.M., Paranoja polityczna. Psychopatologia nienawiści, Wydawnictwo Książka i Wiedza, Warszawa 1999.

Rosa R., Filozofia bezpieczeństwa, Wydawnictwo Bellona, Warszawa 1995.

Rosa R., Filozofia i edukacja do bezpieczeństwa, Wydawnictwo Akademii Podlaskiej, Siedlce 1998.

Rudnik R., Badania nad pokojem w Republice Federalnej Niemiec, Wydawnictwo Wyższej Szkoły Nauczycielskiej, Słupsk 1984.

Ryszka F., Polityka i wojna. Świadomość potoczna a teorie XX wieku, Państwowy Instytutu Wydawniczy, Warszawa 1975.

Safranski R., Zło. Dramat wolności, Wydawnictwo Fundacji ENETHEIA, Warszawa 1999.

Salij J., Autonomia polityki i prawa moralne, „Znak” 1997, nr 7.

Schössler D., Clausewitz, Wydawnictwo Medżarz, Lublin 1995.

Sepkowski A., Człowiek w przestrzeni mitycznej, [w:] Mity historyczno-polityczne - wyobrażenia zbiorowe - polityka historyczna. Studia i materiały, red. E. Ponczek, A. Sepkowski, t. 1, Wydawnictwo Adam Marszałek, Toruń 2010.

Sepkowski A., Mity w wyjaśnianiu naukowym, [w:] Teoretyczne i metodologiczne wyzwania badań politologicznych w Polsce, red. A. Antoszewski, A. Dumała, B. Kraus-Mozer, Wydawnictwo Uniwersytetu Marii Curie-Skłodowskiej, Lublin 2009.

Siedlakowski P., Pedagogika wstydu, „Echo Katolickie” 2014, nr 48.

Sielezin R., Teoretyczne problemy konfliktów społeczno-politycznych i ich specyfika. Próba egzemplifikacji, „Wrocławskie Studia Politologiczne” 2010, nr 11.

Sofsky W., Traktat o przemocy, Wydawnictwo Dolnośląskie, Wrocław 1999.

Spengler O., Człowiek i technika. Przyczynek do filozofii życia, „Kronos”, Kraków 2014.

Spengler O., Zmierzch zachodu, Wydawnictwo Fundacji ENETHEIA, Warszawa 2014.

Stawrowski Z., O niemoralności i moralności polityki, „Znak” 1998, nr 6.

Stępień P., Genetyka agresji, [w:] Człowiek i agresja. Głosy o nienawiści i przemocy. Ujęcie interdyscyplinarne, red. Ł. Jurasz-Dudzik, Wydawnictwo Sic!, Warszawa 2002.

Strumińska-Kutra M., Koładkiewicz I., Studium przypadku, [w:] Badania jakościowe. Metody i narzędzia, red. D. Jemielniak, t. 2, Wydawnictwo Naukowe PWN, Warszawa 2012.

Szacka B., Czas przeszly. Pamięć. Mit, Wydawnictwo Naukowe Scholar, Warszawa 2006.

Świeca J., Z metodologicznych rozważań nad przedmiotem i celem polemologii, „Zeszyty Naukowe Akademii Ekonomicznej w Katowicach" 1986, nr 103.

Świniarski J., Wychowanie dla bezpieczeństwa personalnego i strukturalnego, [w:] Kształcenie i wychowanie w wojsku w toku przemian, red. Z. Markowski, R. Stępień, Wydawnictwo Akademii Obrony Narodowej, Warszawa 1994.

Theiss W., O pedagogii totalitaryzmu, „Bobolanum” 8, 1997.

Topolski J., Wojna jako przedmiot badań historycznych, [w:] Pax et bellum, red. K. Olejnik, Wydawnictwo Uniwersytetu Adama Mickiewicza, Poznań 1993.

Toynbee A., Studium historii. Skrót dokonany przez D.C. Somervella, Państwowy Instytut Naukowy, Warszawa 2000.

Wciórka L., O filozoficznej problematyce zła, „Zeszyty Karmelickie” 1995, nr 3. 
Wojciechowski S., „Sieć” przyczyn współczesnego terroryzmu - analiza czynników, mechanizmów i modeli, „Przegląd Polityczny” 2011, z. 3.

Wojciechowski W., Terroryzm na początku XXI wieku. Pojęcie - przejawy - przyczyny, Wydawnictwo, Contact, Poznań 2013.

Współczesne zagrożenia terroryzmem, red. K. Jałoszyński, Wyższa Szkoła Policji w Szczytnie, Szczytno 2013.

Zadykowicz T., Moralna ocena terroryzmu w świetle jego przyczyn, „Collectanea Theologica” 73, 2003, nr 2.

Zięba R., Nowe podejście do problematyki bezpieczeństwa, [w:] Bezpieczeństwo narodowe i międzynarodowe u schyłku XX wieku, red. D.B. Bobrow, E. Haliżak, R. Zięba, Wydawnictwo Naukowe Scholar, Warszawa 1997.

Zimbardo P., Efekt Lucyfera. Dlaczego dobrzy ludzie czynia zło?, Wydawnictwo Naukowe PWN, Warszawa 2008.

Znaniecki F., Kult państwa, [w:] Polska myśl demokratyczna w ciagu wieków. Antologia, red. M. Kridl et al., Ludowa Spółdzielnia Wydawnicza, Warszawa 1986.

\section{Political conflicts in public space and mass memory}

Keywords: political conflicts, mass memory

\section{Summary}

Conflict provenance must be sought not only in economic conditions, but also in socio-cultural, especially civilizational, religious, ethical and historiosophical ones. Conflict analysis should depend on their profound explanation taking into consideration their axiological and ethical, psychological and historiosophical implications. Conflicts are frequently stimulated due to presentation of various, often extreme, views and explanations of the present, rooted in historical peculiarities of distant or closer past, especially when a tendency to prefer a leading role of affirmed, frequently controversial heroes, appears. 